\title{
1 Context-dependency of agricultural legacies in temperate forest
}

\section{2 soils}

3 Short title: Gradients steer agricultural legacy in forest

4 Authors: Haben Blondeel ${ }^{1}$, Michael P. Perring1,2, Laurent Bergès ${ }^{3}$, Jörg Brunet ${ }^{4}$, Guillaume Decocq ${ }^{5}$,Leen

5 Depauw ${ }^{1}$, Martin Diekmann ${ }^{6}$ Dries Landuyt ${ }^{1}$, Jaan Liira ${ }^{7}$,Sybryn L. Maes ${ }^{1}$, Margot Vanhellemont ${ }^{1}$,

6 Monika Wulf8, Kris Verheyen ${ }^{1}$

$7 \quad$ Corresponding author: haben.blondeel@ugent.be

8 Statement of Authorship: HB, MPP and KV conceived and designed the study with significant

9 contributions from DL, SM and LD. HB, LB, JB, GD, MD, JL and MW assessed historical land use

10 information by investigating sources on historical maps of the focal regions. HB, MPP, JB, GD and JL

11 participated in soil collection in the field. HB, with input from MPP, DL and KV performed subsequent

12 statistical analyses on the data. HB wrote the first draft of the paper. Suggestions were made by KV, MPP,

13 DL and MV, and all authors provided revisions and comments.

\section{Addresses:}

15 1: Forest \& Nature Lab, Campus Gontrode, Faculty of Bioscience Engineering, Ghent University, Geraardsbergsesteenweg 267, 9090 Melle-Gontrode, BELGIUM (mailing address for correspondence)

2: Ecosystem Restoration and Intervention Ecology Research Group, School of Biological Sciences, The University of Western Australia, 35 Stirling Highway, Crawley WA 6009 AUSTRALIA

$19{ }^{3}$ Université Grenoble Alpes, Irstea, UR EMGR, 2 rue de la Papeterie BP 76, F-38402 St-Martin-d'Hères, FRANCE

$21{ }^{4}$ Southern Swedish Forest Research Centre, Swedish University of Agricultural Sciences, Box 49, 23053 Alnarp, SWEDEN

235 Ecologie et Dynamique des Systèmes Anthropisés (EDYSAN, UMR 7058 CNRS), Jules Verne University of Picardie, 1 rue des Louvels, F-80037 Amiens Cedex 1, FRANCE 
256 Vegetation Ecology and Conservation Biology, Institute of Ecology, FB 2, University of Bremen, 26 Leobener Str. 5, DE-28359 Bremen, GERMANY

277 Institute of Ecology and Earth Science, University of Tartu, Lai 40, Tartu, 51005, ESTONIA

288 ZALF, Institute of Land Use Systems, Eberswalder Straße 84, D-15374 Müncheberg, GERMANY 29 


\section{Abstract}

31 Anthropogenic activities have affected forests for centuries, leading to persistent legacies. Observations of agricultural legacies on forest soil properties have been site-specific and contrasting. Sites and regions vary along gradients in intrinsic soil characteristics, phosphorus (P) management and nitrogen (N) deposition which could affect the magnitude of soil property responses to past cultivation. A single investigation along these gradients could reconcile contradictions and elucidate context-dependency in agricultural legacies. We analysed soil from 24 paired post-agricultural (established after approx. 1950) and ancient (in existence before 1850) forests in eight European regions. Post-agricultural forest soil had higher $\mathrm{pH}$, higher $\mathrm{P}$ concentration and lower carbon (C) to $\mathrm{N}$ ratio compared to ancient forest. Importantly, gradients of soil characteristics, regional $\mathrm{P}$ surplus and $\mathrm{N}$ deposition affected the magnitude of these legacies. First, we found that three soil groups, characterising inherent soil fertility, determined extractable base cations, $\mathrm{pH}$ and concentrations of total $\mathrm{N}$, organic $\mathrm{C}$ and total $\mathrm{P}$. Second, regions with greater current $\mathrm{P}$ surplus from agriculture correlated with the highest $\mathrm{P}$ legacy in postagricultural forests. Finally, we found that $\mathrm{N}$ deposition lowered $\mathrm{pH}$ across forests and increased total $\mathrm{N}$ and organic $\mathrm{C}$ concentrations in post-agricultural forest. These results suggest that 1) legacies from cultivation consistently determine soil properties in post-agricultural forest and 2) these legacies depend on regional and environmental context, including soil characteristics, regional P surplus and $\mathrm{N}$ deposition. Identifying gradients that influence the magnitude of agricultural legacies is key to informing how, where and why forest ecosystems respond to contemporary environmental change.

Key words: ancient forest, land-use history, nitrogen deposition, phosphorus, post-agricultural forest, soil carbon

\section{MANUSCRIPT HIGHLIGHTS}

- Regional variables affect soil property responses to prior agriculture in forests

- Accounting for regional context clarifies contrasting agricultural legacies in soils

- Knowing the regional context of forest soils will help project ecosystem responses 


\section{Introduction}

57 Human activities have profoundly affected ecosystems and biodiversity on the long term (Waters and others 2016; Vellend and others 2017). Legacies of past anthropogenic disturbances can obscure ecosystem responses to current disturbance regimes due to time-lags (Bürgi and others 2017) and potentially interact with other global change drivers to steer ecosystem patterns and processes (Perring and others 2016). It is possible for numerous accounts of agricultural legacies in forest soil properties to be contrasting, and site specific when compared to each other (Baeten 2010). Combining observations of agricultural legacies in temperate forest within a single study across regions that vary in gradients of soil characteristics, intensity of agricultural use (phosphorus management) and nitrogen deposition offers the chance to reconcile contrasting findings (Verheyen and others 2017) and elucidate contextdependency in soil responses to agricultural legacy.

\section{Key soil properties for plant growth show contrasting agricultural legacies}

Legacy of agriculture is highly variable and depends on specific management practices that are followed during the agricultural period (McLauchlan 2006; Brudvig and others 2013). Agricultural practices can leave imprints in forest soil properties for centuries (Verheyen and others 1999) and even millennia (Dupouey and others 2002). We focus on five chemical soil properties that are of high importance for plant growth and where previous research has shown differences in the magnitude, or even in the direction, of their responses to prior agriculture in temperate forest: soil organic carbon (C), total nitrogen $(\mathrm{N})$, base cations (calcium (Ca), magnesium $(\mathrm{Mg})$, sodium $(\mathrm{Na})$ and potassium $(\mathrm{K})$ ), $\mathrm{pH}$ and total and bio-available phosphorus (P).

Comparisons of concentrations of soil organic $\mathrm{C}$ and total $\mathrm{N}$ between post-agricultural and continuously forested land (ancient forest) are variable. A lower C concentration and C: $\mathrm{N}$ has been observed in postagricultural forest (Verheyen and others 1999; Foote and Grogan 2010; Yesilonis and others 2016), as well as solely a lower C in post-agricultural forest (Falkengren-Grerup and others 2006; Leuschner and others 2014) and even no difference in C and C:N between post-agricultural forest and ancient forest (Koerner and others 1997; Compton and Boone 2000). Comparisons of base cation stocks are even more 
variable as they can differ within post-agricultural forest sites of single studies (Verheyen and others 1999; Flinn and others 2005), likely due to variations in spatial distribution of nutrients (Fraterrigo and others 2005) and bulk density (Bizzari and others 2015). Despite variable base cation concentrations, a consistently higher $\mathrm{pH}$ in post-agricultural forest occurs due to past fertilisation and liming in postagricultural forests (Wall and Hytönen 2005), but the magnitude of the difference varies (Koerner and others 1997; Verheyen and others 1999; Falkengren-Grerup and others 2006; Grossmann and Mladenoff 2008; Yesilonis and others 2016). Aside from raising $\mathrm{pH}$, past fertilisation also leads to a better retention of total phosphorus (P) in forest soils after tillage (Macdonald and others 2012) in contrast to other disturbance-types such as fires or clearcutting (Grossmann and Mladenoff 2008; Bizzari and others 2015) and extensive pasture (Compton and Boone 2000).

\section{Soil characteristics, phosphorus (P) nutrient management and nitrogen $(N)$ deposition}

\section{could alter soil responses to agricultural legacy}

We identify three gradients that could influence comparisons between soils in post-agricultural and continuously forested sites across multiple regions and thus help explain contrasting site-specific responses.

Firstly, differences in soil characteristics between post-agricultural and continuously forested land (ancient forest) might occur as land for cultivation commonly occurs on the richer soils within a given region (Flinn and others 2005). Factors that would determine the suitability for agriculture are soil texture, wetness, slope, aspect, soil depth and underlying bedrock or parent material. Key topsoil processes are additionally affected by biotic components such as identity of tree species and litter quality in forest stands (Vesterdal and others 2008; De Schrijver and others 2012a; Cools and others 2014; Nitsch and others 2018). Both the abiotic suitability of the site for agriculture and soil-forming biotic processes are local-scale drivers that can cause variability among sites within regions unless explicitly controlled for in a study design, preferably with a paired approach. Furthermore, variations in soil characteristics between regions arise along large spatial gradients as nutrient availability generally decreases in temperate regions at higher latitudes and altitudes (De Frenne and others 2013). 
Second, the intensity of past fertilisation and associated nutrient management will determine the magnitude of legacies' persistence in the forest ecosystem. Region-specific nutrient management practices can influence the magnitude of response in soil properties more than the actual agricultural land-use type. Macdonald and others (2012) illustrated this by showing that soil P legacies arose more prominently across regions than between types of agricultural land use practiced prior to abandonment within each region. The regional phosphorus balance could reflect how nutrient management of phosphorus occurs within sites at a regional level. This is because the region is a collection of local farms, where each farm reports its total amount of $\mathrm{P}$ applied on fields, as well as its total outflow from harvest and grazing (see the report to the European Commission by Bomans and others 2005). Farm practices in regions with a surplus of $\mathrm{P}$ have often included excessive manuring of fields and meadows (Ringeval and others 2017) leading to long-term accumulation of P with major consequences for the environment and global nutrient management (Sattari and others 2012; Rowe and others 2016; Bouwman and others 2017).

Finally, $\mathrm{N}$ deposition is a global change driver that varies regionally and originates from intensive agriculture (fertilisation and animal husbandry) and burning of fossil fuels (Bobbink and others 2010). Acidification and eutrophication are effects of reactive $\mathrm{N}$ that influence ecosystem composition and function (De Schrijver and others 2011) at an ecosystem-specific critical load (Bobbink and others 2015). Critical loads for different deciduous forest types range from 10 to $20 \mathrm{~kg} \mathrm{~N} \mathrm{ha}^{-1} \mathrm{y}^{-1}$ (Bobbink and others 2010, 2015; Simkin and others 2016). Exceedance of critical loads potentially leads to leaching of compounds following acidification (Bobbink and others 2010). Eutrophication of the soil occurs by an enrichment of N (Bobbink and others 2010), which can lead to nutrient imbalances in plants e.g. chronic shortages of P (Tao and Hunter 2012) unless supply of P is enhanced through other mechanisms such as increased phosphatase activity (Perring and others 2008). Nitrogen enrichment is therefore expected to alter P dynamics and legacies of prior fertilization in post-agricultural soils.

\section{Hypothesis: legacies of prior agriculture in temperate forest are context-dependent}

Based on the published literature, we expect legacies of prior agriculture for five chemical soil properties important for plant growth when combining measurements from paired sites of post- 
agricultural and continuously forested land (ancient forest). More precisely, we expect higher concentrations of $\mathrm{P}$ and base cations, higher $\mathrm{pH}$, lower concentrations of $\mathrm{C}$ and lower $\mathrm{C}: \mathrm{N}$ in postagricultural forest. The magnitude of these legacies are expected to be affected by gradients of soil characteristics, agricultural intensity and $\mathrm{N}$ deposition thus exhibiting a context-dependency:

1. Inherent soil characteristics relate to texture and underlying parent material of soil deposits, but equally to other edaphic factors such as wetness, relief and exposure. We expect that several variable observations of soil legacies (such as responses of base cations) between pairs of sites and multiple regions are attributable to differences in soil characteristics.

2. The magnitude of the cultivation legacy in post-agricultural forest soil will for one be relative to prior fertilisation intensity and nutrient management on the regional level. Such intensity could be reflected in concentrations of $\mathrm{P}$ due to its biogeochemical properties and potential of prolonged adsorption in the soil. In the absence of historical data, we test whether contemporary regional $\mathrm{P}$ surplus is associated with a higher legacy in soil $\mathrm{P}$ concentrations in post-agricultural forests compared to the regions' ancient forests.

3. $\mathrm{N}$ deposition varies widely on the regional level, where we expect that higher rates of deposition increase responses of acidification $(\mathrm{pH})$ and eutrophication $(\mathrm{N})$, with possible side effects on $\mathrm{P}$ availability dependent on the land-use history of the site.

\section{Materials and Methods}

Selection of regions along gradients of soil characteristics, regional $P$ balance and $N$ deposition

We selected eight regions across gradients of soil characteristics, regional P balance (surplus of P) and $\mathrm{N}$ deposition within temperate Europe (Figure 1). These regions span from Pärnu county in the Lääne-

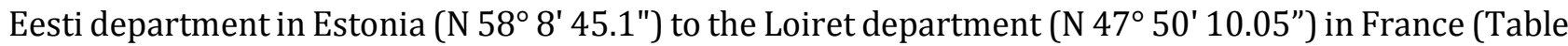
1). We define a region as a large-scaled area with homogeneous macro-climatic conditions (mean annual temperature and precipitation) and topography (Table 1). For this purpose, we adopt the third level of the Nomenclature of Territorial Units for Statistics (NUTS) by the European Union (2015) for our regional 
boundaries (Table 1). We aggregated multiple NUTS-III entities to one region where the administrative boundaries were too detailed or where forest patches were on the border of two neighbouring entities (Table 1).

Invariable soil characteristics such as texture and underlying parent material of soil deposits can differ between post-agricultural and ancient forest within and across regions. To isolate legacy effects of prior agriculture in our comparison of ancient and post-agricultural forest soils, rather than detecting that sites with agricultural history occur on richer soils, we utilised a paired-plot approach within regions (Foote and Grogan 2010; Brudvig and others 2013; Bizzari and others 2015). Thus, we attempted to ensure that local inherent soil characteristics varied minimally within a given pair (Table 1, WRB classifications) while simultaneously controlling for overstorey composition (de la Peña and others 2016, see Supplementary Table S1.3). Differences in inherent soil characteristics between pairs (landscape scale) and the regional scale allows analysing responses to agriculture's legacy in relation to gradients in inherent soil characteristics.

Agricultural intensity on the regional level is estimated by the nutrient balance for P from a report of the Soil Service of Belgium for the year 2003 to the European commission (Bomans and others 2005). This is calculated per region on NUTS-II and III-levels as the total inflow of P that farmers report to their local governments (fertilisation and manure production) subtracted with the total outflow (harvest and grazing), formulating a regional nutrient balance when expressed per area of agricultural land (kg P ha1). A positive balance (surplus) indicates an excess of $\mathrm{P}$ with potential risk of accumulation and eutrophication by leaching. A negative or zero balance indicates a potential depletion of nutrients. In absence of historical data for P nutrient balances in European regions, we resort to the use of the contemporary values for the P nutrient management in these areas (Bomans and others 2005). We expect that the relative differences of the $\mathrm{P}$ balance between the regions would still hold when using contemporary values for a historical context, i.e. we assume that regions with the highest current surplus likely also had the highest P surplus during the mid-20th century. This assumption would be worthy of further investigation. 
The magnitude of $\mathrm{N}$ deposition between 1990 and 2010 has proven to be an important determinant of the adverse effects of reactive $\mathrm{N}$ in forest ecosystems (Dirnböck and others 2017). Interpolated values of model results from the EMEP database (version 2013, http://www.emep.int/) for the year 2000 were therefore used as the annual nitrogen deposition variable. The critical load concept highlights that we have robustly covered ecologically important variation in our choice of sites. For instance, two regions (OR, EST) are found below typical critical load exceedances while, at the other extreme, two regions (VL, $\mathrm{BR}$ ) have $\mathrm{N}$ deposition well in excess of a temperate forest understorey threshold of $18 \mathrm{~kg} \mathrm{~N} \mathrm{ha}^{-1} \mathrm{y}^{-1}$ (Bobbink and others 2015; Simkin and others 2016).

\section{Selection of forest patches and determining their land-use history}

We searched for three pairs of ancient and post-agricultural broadleaved forests in each of the eight regions, leading to 48 forest patches included in the study. These pairs consisted of forest patches that are nearby in a landscape context, with the median distance between two pairs being $760 \mathrm{~m}$ (supplementary information, Table S1.1). This paired approach allows for minimising differences in site characteristics such as texture, aspect and wetness and allows for isolating the legacies of previous land management rather than inherent differences of post-agricultural and ancient forest sites (Flinn and others 2005; Brudvig and others 2013). Forest types were mainly mesophytic with fresh deep soils and sandy to loamy soil textures (see Soil World Reference Base in Table 1).

The land-use history of these forest patches was determined by use of historical land-use maps (see Supplementary information Table S1.2), which pre-dated 1850 for most regions. Forests that have been continuously present on land-use maps since the earliest reliable recording are considered as ancient while reforestations on abandoned fields during mid-20 th century are considered post-agricultural (Peterken 1996). This “binary” approach (Bürgi and others 2017) for classifying land-use history types (or land-cover types) has the drawback that subtleties in land management transitions might be missed, potentially leading to contrasting legacies of past agriculture. We minimised this issue by confining the period of cultivation abandonment to around 1950 (Cramer and others 2008) and by gathering data from multiple regions (Macdonald and others 2012; Verheyen and others 2017). 
Canopy composition within paired forest patches was ideally as similar as possible and sharing multiple tree species (supplementary information, Table S1.3). The forest canopy often consisted of Quercus robur/petraea, Fraxinus excelsior, Acer pseudoplatanus and Fagus sylvatica. Patches with presence of Alnus sp. were avoided due to unwanted confounding of $\mathrm{N}$ fixation effects, as well as being an indicator for high soil moisture content (idem with Salix). Presence of coniferous species was kept at a minimum, but a higher incidence in the northernmost region (EST) was unavoidable.

\section{Soil collection and physicochemical analyses}

We collected a large volume of soil $\left(\mathrm{ca} 0.1 \mathrm{~m}^{3}\right)$ in each forest patch from a pit with a depth of $15 \mathrm{~cm}$ and surface of $70 \times 100 \mathrm{~cm}$. Roots, drainage lines and wet depressions were avoided as a location for sampling in the forest stands. The field campaign ran from October 2015 until February 2016 and its primary purpose was to provide material for a large mesocosm experiment, necessitating the collection strategy used even though composited samples could have been more representative for the entire forest patch. All 48 bulk soil samples were separately sieved ( $4 \mathrm{~mm}$ mesh, $5 \mathrm{~mm}$ for heavy soils) for homogenization and removing of coarse organic material. We subsampled $500 \mathrm{ml}$ from the $0.1 \mathrm{~m}^{3}$ of homogenized soil and processed this through a $1 \mathrm{~mm}$ sieve for chemical analysis. Prior to chemical analysis, soil was dried to constant weight at $40^{\circ} \mathrm{C}$ for $48 \mathrm{~h}$.

We analysed samples for $\mathrm{pH}-\mathrm{H}_{2} \mathrm{O}$ by shaking a 1:5 ratio soil/ $\mathrm{H}_{2} \mathrm{O}$ mixture for $5 \mathrm{~min}$ at $300 \mathrm{rpm}$ and measuring with a pH meter Orion 920A with a pH electrode model Ross sure-flow 8172 BNWP, Thermo Scientific Orion, USA (Norm: ISO 10390:199). Total C (\%) and N (\%) concentrations were quantified by combusting samples at $1200^{\circ} \mathrm{C}$ which releases all $\mathrm{C}$ and $\mathrm{N}$ and then measuring the combustion gases for thermal conductivity in a CNS elemental analyser (vario Macro Cube, Elementar, Germany). Inorganic C content was measured after $1 \mathrm{~g}$ of dry soil was ashed for 4 hours at $450^{\circ} \mathrm{C}$ by gradually increasing temperature. This procedure drives off organic $\mathrm{C}$ leaving only mineral carbon in the ashes, which were measured using a CNS elemental analyser. Subtracting inorganic C from total C gives the organic C (\%). This organic $\mathrm{C}$ metric was used to calculate the $\mathrm{C}: \mathrm{N}$ ratio by taking the ratio of organic $\mathrm{C}$ to total $\mathrm{N}$.

Extraction of mobile soil cations ( $\mathrm{Ca}, \mathrm{K}, \mathrm{Mg}$, $\mathrm{Na}$, and $\mathrm{Al}$ ) was performed by extracting soil samples with a 1:5 soil:extractant ratio with ammonium lactacte which consisted of lactic acid (88\%), acetic acid 
(99\%) and ammonium acetate (25\%) at $\mathrm{pH} 3.74$.The cations were measured using atomic absorption spectrophotometry. The proportion of exchangeable base cations was calculated by converting the values from $\mathrm{mg} / \mathrm{kg}$ to $\mathrm{meq} / \mathrm{kg}$ so that charge of the cations is included, and then taking the ratio of the sum $\mathrm{K}^{+} \mathrm{Ca}^{2+}, \mathrm{Mg}^{2+}$ and $\mathrm{Na}^{+}$over the sum of $\mathrm{K}^{+}, \mathrm{Ca}^{2+}, \mathrm{Mg}^{2+}, \mathrm{Na}^{+}$and $\mathrm{Al}^{3+}$. Total $\mathrm{Ca}$ and $\mathrm{Fe}$-concentration was measured by atomic absorption spectrophotometry (AA240FS, Fast Sequential AAS) after complete digestion of the soil samples with $\mathrm{HClO}_{4}(65 \%), \mathrm{HNO}_{3}(70 \%)$ and $\mathrm{H}_{2} \mathrm{SO}_{4}(98 \%)$ in teflon bombs for $4 \mathrm{~h}$ at $150^{\circ} \mathrm{C}$. All P-concentrations were measured colorimetrically according to the malachite green procedure (Lajtha and others 1999). Total $\mathrm{P}$ was extracted after complete digestion of the soil samples with $\mathrm{HClO}_{4}$ (65\%), $\mathrm{HNO}_{3}(70 \%)$ and $\mathrm{H}_{2} \mathrm{SO}_{4}(98 \%)$ in teflon bombs for $4 \mathrm{~h}$ at $150^{\circ} \mathrm{C}$. Soluble and readily soluble $\mathrm{P}$ was extracted in $\mathrm{CaCl}_{2}\left(\mathrm{P}_{\mathrm{Cacl} 2}\right.$; Simonis and Setatou 1996). Bioavailable $\mathrm{P}$, which is available for plants within one growing season (Gilbert and others 2009), was extracted in NaHCO3 ( $\mathrm{P}_{\text {olsen }}$ according to ISO 11263:1994(E)).

Soil texture (\% Clay, \% Sand \% Silt,) was analysed with laser diffraction (Coulter Laser LS 13320 (SIP050D2) with auto-sampler) after removal of organic material with $\mathrm{H}_{2} \mathrm{O}_{2}$ (28.5\%) and dispersing the sample with Sodium polyphosphate (6\%).

\section{Data analysis}

All data analyses and handling was performed in R (R Core Team 2017). Firstly, we clustered data on invariable soil properties related to soil texture and properties of calcareous bedrock (Clay, Silt, Sand and concentrations of total Ca, total Fe and inorganic C, Supplementary information Figure S2.1) using the hclust function in R (R Core Team 2017). The three resulting clusters from this analysis were used as a categorical variable "Soil group" in the statistical analyses. The results from the cluster analysis were subsequently analysed for principal components to check how the soil groups from the cluster analysis align with all centered and scaled continuous variables to aid in interpretation (Supplementary information Figure S2.2). In addition, we calculated correlations between all soil variables with Spearman's rank correlation coefficients (Supplementary information Figure S2.3) to aid the interpretation of the soil clustering procedure, the principal component analysis and our a priori selection of response variables. We apply the relative terms 'Eutrophic', 'Mesotrophic' and 'Oligotrophic' 
to our soil groups as they reflect major differences in soil fertility between our study forests (as in Hirst and others 2005; Balkovič and others 2012). Principal component analysis (Supplementary information Figure S2.2) shows that alignment of Eutrophic soil groups with concentrations of inorganic $\mathrm{C}$ and total Ca indicate the calcareous properties of these soil groups, resulting in higher $\mathrm{pH}$ and proportion of extractable base cations (BC). Mesotrophic soils adopt an overall intermediate position in soil properties, which is visualised in their position around the origin of the principal component analysis. Oligotrophic soils align with high Sand and a high C:N which both correlate with high acidity and lower nutrient concentration (Supplementary information Figure S2.3).

We then tested whether land-use history's $(L U H)$ effect on $p H$, organic carbon $(\operatorname{org} C)$, total nitrogen (tot $N)$, $C: N$, proportion of extractable base cations $(B C)$, total phosphorus $\left(P_{\text {total }}\right)$ and bio-available phosphorus $\left(P_{\text {olsen }}\right)$ was context dependent by considering the gradients of invariable soil characteristics (Soil group), nitrogen deposition (Ndep), and P nutrient management ( $P$-balance). The land use-history of the forest is a categorical variable with two levels indicating whether a forest is continuously forested since at least 1850 (Ancient) or whether a forest has been established around 1950 on abandoned arable land (Post-agricultural). Soil group is a categorical variable with three levels that reflects the inherent soil fertility, as the variable is a product of the cluster analysis on soil properties that relate to texture and calcareous bedrock. To test whether legacies of prior agriculture depend on the soil group, an interaction of $L U H^{*}$ Soil group was added in the explanatory models along with the constituent main effects (hypothesis 1). Testing the dependence of agricultural legacies in soil properties along the nitrogen deposition gradient was conducted by adding an interaction term of $L U H^{*} N d e p$ (hypothesis 3 ). These two interaction terms and their main effects formed the fixed factors of the base model (Equation 1). The interaction of Ndep and Soil group was not included in this model due to a limited spread of one soil group (eutrophic) along the $\mathrm{N}$ deposition gradient. To test whether total and bio-available phosphorus concentrations in post-agricultural forest are higher in regions with greater P surplus (hypothesis 2), we add in an extra interaction term between $L U H^{*} P$-balance to model responses of total phosphorus $\left(P_{t o t a l}\right)$ and bio-available phosphorus $\left(P_{\text {olsen }}\right)$. The phosphorus balance could also interact with nitrogen deposition to determine responses of $P_{\text {total }}$ and $P_{\text {olsen }}$ (hypothesis 3 ) so a final term of 
of hierarchical mixed-effects models to test these effects, using the lme4 package and the function Imer (Bates and others 2014) with Pair within Region incorporated as a nested random effect. We used maximum likelihood estimation to allow the calculation of a likelihood ratio test when comparing between models.

$$
\begin{gathered}
\text { Response variable } \sim L U H+\text { Soil group }+N d e p+L U H * \text { Soil group }+L U H * N d e p \\
+(1 \mid \text { Region/Pair })
\end{gathered}
$$

Equation 1: base model

$$
P \sim \text { base model }+P \text {-balance }+L U H * P \text {-balance }+N \text { dep } * P \text {-balance }+(1 \mid \text { Region/Pair })
$$

\section{Equation 2: Expanded base model with $P$ balance as an additional interactive term to test responses of soil $P$} We then found the most parsimonious models for explaining variation in each response variable using stepwise backwards model selection and a Chi-squared test in the drop1 function (R Core Team 2017) for calculation of $\mathrm{p}$-values on the likelihood ratio statistic. We consider $\mathrm{p}<0.05$ as significant and $\mathrm{p}<0.1$ as supporting minor evidence for an effect. Non-significant interactions with the highest $\mathrm{p}$-values were left out of the models first, prior to testing the constituent main effects. Main effects were retained, even if non-significant, if they appeared in interaction terms. Normality of the residuals in the final model was controlled by performing a Shapiro-Wilk test with the shapiro.test function (R Core Team 2017). If normality in the residuals could not be assumed, a log transformation of the response variable was performed for right-tailed response variables and a squared transformation with left-tailed response variables. Goodness-of-fit $\left(\mathrm{R}^{2}\right.$ values) for linear mixed effects models were calculated using the r.squaredGLMM function from the MuMIn package (Barton 2017), which lists both the marginal $\mathrm{R}^{2}$ (variance explained by fixed factors only) and the conditional $\mathrm{R}^{2}$ (variance explained by both fixed and random effects, Nakagawa and Schielzeth 2013))

\section{Results}

Post-agricultural forest had significantly $(\mathrm{p}<0.05)$ higher $\mathrm{pH}$, higher phosphorus concentration $\left(\mathrm{P}_{\text {olsen }}\right.$ and $\left.\mathrm{P}_{\text {total }}\right)$ and lower C:N compared to ancient forest (Figure 2 and Table 2). Soil group affected responses of $\mathrm{pH}$, proportion of extractable base cations and total $\mathrm{P}$ concentration $(\mathrm{p}<0.05)$ as main effects, with the highest values of these three variables in rich "eutrophic" soils and the lowest values in the poor 
"oligotrophic" soils, with "mesotrophic" soil having intermediate means. Higher $\mathrm{N}$ deposition is associated with lower $\mathrm{pH}(\mathrm{p}<0.05)$ across all forest sites as a main effect. Crucially, we found that gradients of soil characteristics, $\mathrm{P}$ nutrient management and $\mathrm{N}$ deposition affected the magnitudes of organic $\mathrm{C}$, total $\mathrm{N}$, bio-available Olsen $\mathrm{P}$ and total $\mathrm{P}$ concentrations in interaction with the forests' landuse history (Figure 2, Table 2).

Firstly, we found minor evidence for a dependence of total $\mathrm{N}$ concentration on the land-use history between soil groups $(\mathrm{p}<0.1)$, as lower total $\mathrm{N}$ concentrations in post-agricultural forest only occurred in mesotrophic and oligotrophic soils (Table2).

Secondly, we found that the magnitude of phosphorus (P) legacy in post-agricultural forest is dependent on the regions' phosphorus balance, with higher $\mathrm{P}$ concentrations in regions with greater surplus of $\mathrm{P}$. The interaction term for land-use history and $\mathrm{P}$ balance (which we assume is a proxy for nutrient management intensity of past agriculture) is significant for modelling responses of $P_{\text {total }}(p<0.05)$ but only with minor evidence for $\mathrm{P}_{\text {olsen }}(\mathrm{p}<0.1)$.

Finally, we found interactions of $\mathrm{N}$ deposition and land-use history on concentrations of organic $\mathrm{C}$ $(\mathrm{p}<0.05)$ but with minor evidence on total $\mathrm{N}(\mathrm{p}<0.1)$ We found higher total $\mathrm{N}$ and organic $\mathrm{C}$ concentrations in post-agricultural forest with increasing $\mathrm{N}$ deposition while total $\mathrm{N}$ and organic $\mathrm{C}$ concentrations in ancient forest remained unchanged (Table 2 and Figure 2).

\section{Discussion}

Combining soil data from 24 paired sites of ancient and post-agricultural forests across eight European regions successfully elucidated consistent legacies of past land use. As expected, we observed an overall higher $\mathrm{P}$ concentration, higher $\mathrm{pH}$, and lower $\mathrm{C}: \mathrm{N}$ ratio in post-agricultural forest compared to ancient forest. The magnitude of these legacies was affected by gradients of soil characteristics, $\mathrm{P}$ nutrient management on the regional level, and $\mathrm{N}$ deposition thus exhibiting a context-dependency. First, we found that three soil groups characterised the inherent fertility of the soils and determined the proportion of extractable base cations, $\mathrm{pH}$ and concentrations of total $\mathrm{N}$, organic $\mathrm{C}$ and total $\mathrm{P}$. Second, regions with greater current surplus of $\mathrm{P}$ from agriculture experienced the highest $\mathrm{P}$ legacy in post- 
agricultural forests. Finally, we found that increasing $\mathrm{N}$ deposition coincided with a lower $\mathrm{pH}$ across forests and increasing total $\mathrm{N}$ and organic $\mathrm{C}$ concentrations in post-agricultural forest. These results suggest that 1) land-use legacies from cultivation consistently determine soil property responses in post-agricultural forest and 2) differences in the magnitude of response to land-use history can relate to the regional and environmental context, including soil characteristics, regional surplus of $\mathrm{P}$ and nitrogen deposition.

Inherent soil characteristics are important when comparing legacies of prior agriculture between regions and sites as portrayed in the difference in the proportion of extractable base cations, $\mathrm{pH}$ and agricultural phosphorus legacies that we observed between the three soil groups (hypothesis 1). Forests on abandoned fields with carbonate and clay-rich soils exhibited the highest total P concentrations (694 $\mathrm{mg} \mathrm{P} / \mathrm{kg}$ ), likely due to strong retention of $\mathrm{P}$ after cultivation (von Wandruszka 2006). This result was in contrast to ancient forest on sandy oligotrophic soil $(292 \mathrm{mg} / \mathrm{kg})$, as these soils are capable of retaining $\mathrm{P}$ only by adsorption with $\mathrm{Fe} / \mathrm{Al}$ oxides which is generally lower than sorption by clay minerals (Gérard 2016). The large regional differences in soil characteristics consequently determined the $\mathrm{P}$ legacy effect.

The magnitude of phosphorus legacy in post-agricultural forest was furthermore affected by the $\mathrm{P}$ immediate biological uptake (Gilbert and others 2009), and consists of phosphate in the soil solution or phosphate that can rapidly desorb or mineralise from inorganic or organic soil compounds (De Schrijver and others 2012b). In Flanders (Belgium), a region with a $20 \mathrm{~kg}$ surplus of $\mathrm{P}$ per ha of agricultural land, $\mathrm{P}_{\text {olsen }}$ in post agricultural forest was on average $56.3 \mathrm{mg} / \mathrm{kg}$, which was more than triple the $15.5 \mathrm{mg} / \mathrm{kg}$ in paired ancient forests. A biological consequence of this dependence of $\mathrm{P}$ legacy on regional $\mathrm{P}$ balance 
and others 2002; Baeten and others 2010) and are therefore likely less inhibited in areas with a lower P balance (Brunet and others 2012).

Study regions with higher $\mathrm{N}$ deposition exhibited responses of acidification and eutrophication in respectively $\mathrm{pH}$ and concentration of total $\mathrm{N}$ as hypothesized (hypothesis 3 ). The $\mathrm{pH}$ was 0.56 units lower across soil groups for each $10 \mathrm{~kg} \mathrm{~N} \mathrm{ha}^{-1} \mathrm{y}^{-1}$ of deposition. This acidifying response magnifies the risk that $\mathrm{Fe} / \mathrm{Al}$ oxides leach in poorly buffered oligotrophic soils (Lukac and Godbold 2011), underlining that these systems are most susceptible to acidification (Bobbink and others 2015). Aside from acidification, greater $\mathrm{N}$ deposition is associated with increased organic $\mathrm{C}$ and total $\mathrm{N}$ concentration but only in post-agricultural forest. We identify two possible explanations why we found signals of an accumulation of soil organic matter in post-agricultural forest under high $\mathrm{N}$ deposition. First, decomposer communities of post-agricultural forests may be less adapted to decomposition in high acidity than decomposer communities of ancient forest (Fichtner and others 2014; Tardy and others 2015). Second, it is likely that $\mathrm{N}$ deposition has stimulated an acceleration in forest growth and $\mathrm{C}$ storage in young temperate deciduous forests (Pretzsch and others 2014; Fowler and others 2015). This dependence of $\mathrm{N}$ deposition on forest land-use history on responses of organic $\mathrm{C}$ and total $\mathrm{N}$ could reveal why responses of eutrophication by $\mathrm{N}$ deposition were found to be less clear in temperate forests as opposed to other ecosystems such as grassland and heathland (Bobbink and others 2010; De Schrijver and others 2011; Verheyen and others 2012, but see Dirnböck and others 2014) .

Legacies of prior agriculture can be important drivers of global change (Foster and others 2003) in temperate forest in interaction with other environmental changes (Perring and others 2016). With our results, we show that agricultural legacies across temperate forest sites are elucidated when considering differing soil characteristics, regional phosphorus nutrient management and nitrogen deposition on a regional level. Identifying gradients that have influenced the magnitude of agricultural legacies is key to informing how, where and why forest ecosystems respond to contemporary environmental change. 
We thank the European Research Council for funding this research through the PASTFORWARD project

[ERC Consolidator Grant 614839, attributed to KV]. We thank the Research Foundation - Flanders

(FWO) for funding the scientific research network FLEUR (http://www.fleur.ugent.be) as this network

proved to be a helpful platform for finding study regions and supporting DL. Many colleagues from the

Forest \& Nature Lab provided valuable input in completion of this work. Robbe De Beelde, Filip Ceunen

and Kris Ceunen helped considerably in the soil collection campaign. Luc Willems and Greet de Bruyn

performed soil chemical analyses. Stephanie Schelfhout and An De Schrijver provided references for soil chemical analyses and P related literature. We thank Gerrit Genouw from the Research Institute Nature

and Forest (INBO) for arranging soil texture analyses. Multiple persons helped in relocating forest patch locations or reconstructing their history and granting access. Our gratitude goes out to Pieter De Becker,

Peter Van de Kerckhove, Kris Vandekerkhove, Marc Esprit, Hilaire Martin, Frédéric Archaux, Emilie

Gallet-Moron, Henri de Witasse de Thézy, Thierry Kervin and Mme. Laudelot.

\section{References}

Baeten L. 2010. Recruitment and performance of forest understorey plants in post-agricultural forests. PhD Thesis, Ghent University.

Baeten L, Vanhellemont M, Frenne PDE, Hermy M, Verheyen K. 2010. The phosphorus legacy of former agricultural land use can affect the production of germinable seeds. Ecoscience 17:365-71.

Balkovič J, Kollár J, Šimonovič V. 2012. Experience with using Ellenberg's R indicator values in Slovakia: Oligotrophic and mesotrophic submontane broad-leaved forests. Biologia 67:474-82.

Barton K. 2017. MuMIn: Multi-model Inference. URL: https://CRANR-project.org/package=MuMIn.

Bates D, Mächler M, Bolker B, Walker S. 2014. Fitting Linear Mixed-Effects Models using lme4. Journal of Statistical Software 67:1-48.

Bizzari LE, Collins CD, Brudvig LA, Damschen EI. 2015. Historical agriculture and contemporary fire frequency alter soil properties in longleaf pine woodlands. Forest Ecology and Management 349:45-54.

Bobbink R, Hicks K, Galloway J, Spranger T, Alkemade R, Ashmore M, Bustamante M, Cinderby S, Davidson E, Dentener F, Emmett B, Erisman JW, Fenn M, Gilliam F, Nordin A, Pardo L, De Vries W. 2010. Global assessment of nitrogen deposition effects on terrestrial plant diversity: A synthesis. Ecological Applications 20:30-59. 
Bobbink R, Tomassen H, Weijters M, van den Berg L, Braun S, Nordin A, Schütz K, Hettelingh JP. 2015. Chapter 4: Effects and Empirical Critical Loads of Nitrogen for Europe. In: Critical Loads and Dynamic Risk Assessments. Vol. 25. pp 297-326.

Bomans E, Fransen K, Mertens J, Michiels P, Vandendriessche H, Vogels N. 2005. Addressing phosphorus related problems in farm practice. Soil Service of Belgium, Leuven-Heverlee 32.

Bouwman AF, Beusen AHW, Lassaletta L, van Apeldoorn DF, van Grinsven HJM, Zhang J, Ittersum van MK. 2017. Lessons from temporal and spatial patterns in global use of $\mathrm{N}$ and $\mathrm{P}$ fertilizer on cropland. Scientific Reports 7:1-11.

Brudvig LA, Grman E, Habeck CW, Orrock JL, Ledvina JA. 2013. Strong legacy of agricultural land use on soils and understory plant communities in longleaf pine woodlands. Forest Ecology and Management 310:944-55.

Brunet J, Frenne P De, Holmström E, Lajos M. 2012. Life-history traits explain rapid colonization of young post-agricultural forests by understory herbs. Forest Ecology and Management 278:55-62.

Bürgi M, Östlund L, Mladenoff DJ. 2017. Legacy Effects of Human Land Use: Ecosystems as TimeLagged Systems. Ecosystems 20:94-103.

Compton JE, Boone RD. 2000. Long-term impacts of agriculture on soil carbon and nitrogen in New England forests. Ecology 81:2314-30.

Cools N, Vesterdal L, De Vos B, Vanguelova E, Hansen K. 2014. Tree species is the major factor explaining C: $\mathrm{N}$ ratios in European forest soils. Forest Ecology and Management 311:3-16.

Cramer VA, Hobbs RJ, Standish RJ. 2008. What's new about old fields? Land abandonment and ecosystem assembly. Trends in Ecology and Evolution 23:104-12.

De Frenne P, Graae BJ, Rodríguez-Sánchez F, Kolb A, Chabrerie 0, Decocq G, De Kort H, De Schrijver A, Diekmann M, Eriksson O, Gruwez R, Hermy M, Lenoir J, Plue J, Coomes DA, Verheyen K. 2013. Latitudinal gradients as natural laboratories to infer species' responses to temperature. Journal of Ecology 101:784-95.

de la Peña E, Baeten L, Steel H, Viaene N, De Sutter N, De Schrijver A, Verheyen K. 2016. Beyond plant soil feedbacks : mechanisms driving plant community shifts due to land-use legacies in postagricultural forests. Functional Ecology 30:1073-85.

De Schrijver A, De Frenne P, Ampoorter E, van Nevel L, Demey A, Wuyts K, Verheyen K. 2011. Cumulative nitrogen input drives species loss in terrestrial ecosystems. Global Ecology and Biogeography 20:803-16.

De Schrijver A, De Frenne P, Staelens J, Verstraeten G, Muys B, Vesterdal L, Wuyts K, van Nevel L, Schelfhout S, De Neve S, Verheyen K. 2012a. Tree species traits cause divergence in soil acidification during four decades of postagricultural forest development. Global Change Biology 18:1127-40.

De Schrijver A, Vesterdal L, Hansen K, De Frenne P, Augusto L, Achat DL, Staelens J, Baeten L, De Keersmaeker L, De Neve S, Verheyen K. 2012b. Four decades of post-agricultural forest development have caused major redistributions of soil phosphorus fractions. Oecologia 169:22134.

Dirnböck T, Foldal C, Djukic I, Kobler J, Haas E, Kiese R, Kitzler B. 2017. Historic nitrogen deposition 
determines future climate change effects on nitrogen retention in temperate forests. Climatic Change 144:221-35.

Dirnböck T, Grandin U, Bernhardt-Römermann M, Beudert B, Canullo R, Forsius M, Grabner M, Holmberg M, Kleemola S, Lundin L, Mirtl M, Neumann M, Pompei E, Salemaa M, Starlinger F, Staszewski T, Uzieblo K. 2014. Forest floor vegetation response to nitrogen deposition in Europe. Global change biology 20:429-40.

Dupouey AJL, Dambrine E, Laffite JD, Moares C. 2002. Irreversible Impact of past Land Use on Forest Soils and Biodiversity. Ecolgy 83:2978-84.

European Union. 2015. Regions in the European Union: Nomenclature of territorial units for statistics NUTS 2013/EU-28. Eurostat, Luxembourg

Falkengren-Grerup U, ten Brink D-J, Brunet J. 2006. Land use effects on soil N , P , C and pH persist over 40 - 80 years of forest growth on agricultural soils. Forest Ecology and Management 225:74-81.

Fichtner A, von Oheimb G, Härdtle W, Wilken C, Gutknecht JLM. 2014. Effects of anthropogenic disturbances on soil microbial communities in oak forests persist for more than 100 years. Soil Biology and Biochemistry 70:79-87.

Fisher RF, Binkley D. 2000. Soil chemistry and nutrient uptake - Phosphate and sulfate concentrations depend on specific adsorption. In: Ecology and Management of Forest Soils. pp 106-7.

Flinn KM, Vellend M, Marks PL. 2005. Environmental causes and consequences of forest clearance and agricultural abandonment in central New York, USA. Journal of Biogeography 32:439-52.

Foote RL, Grogan P. 2010. Soil carbon accumulation during temperate forest succession on abandoned low productivity agricultural lands. Ecosystems 13:795-812.

Foster D, Swanson F, Aber J, Burke I, Brokaw N, Tilman D, Knapp A. 2003. The Importance of Land-Use Legacies to Ecology and Conservation. BioScience 53:77-88.

Fowler ZK, Adams MB, Peterjohn WT. 2015. Will more nitrogen enhance carbon storage in young forest stands in central Appalachia? Forest Ecology and Management 337:144-52.

Fraterrigo J, Turner M, Pearson SM, Dixon P. 2005. Effects of past land use on spatial heterogeneity of soil nutrients in southern Appalachian forests. Ecological Monographs 75:215-30.

Gérard F. 2016. Clay minerals, iron/aluminum oxides, and their contribution to phosphate sorption in soils - A myth revisited. Geoderma 262:213-26.

Gilbert J, Gwonig D, Wallace H. 2009. Available soil phosphorus in semi-natural grasslands: Assessment methods and community tolerances. Biological Conservation 142:1074-83.

Grossmann EB, Mladenoff DJ. 2008. Farms, fires, and forestry: Disturbance legacies in the soils of the Northwest Wisconsin (USA) Sand Plain. Forest Ecology and Management 256:827-36.

Hirst RA, Pywell RF, Marrs RH, Putwain PD. 2005. The resilience of calcareous and mesotrophic grasslands following disturbance. Journal of Applied Ecology 42:498-506.

Honnay O, Bossuyt B, Verheyen K, Butaye J, Jacquemyn H, Hermy M. 2002. Ecological perspectives for the restoration of plant community in European temperate forests. Biodiversity and Conservation 11:213-42. 
Koerner W, Dupouey JL, Dambrine E, Benoit M. 1997. Influence of Past Land Use on the Vegetation and Soils of Present Day Forest in the Vosges Mountains, France. Journal of Ecology 85:351-8.

Lajtha K, Driscoll CT, Jarrell WM, Elliott ET. 1999. Soil phosphorus: characterization and total element analysis. In: Robertson David C.;Bledsoe, Caroline S.;Sollins, Phillip GP, editor. Standard soil methods for long-term ecological research. New York, NY: Oxford University Press

Leuschner C, Wulf M, Bäuchler P, Hertel D. 2014. Forest Continuity as a Key Determinant of Soil Carbon and Nutrient Storage in Beech Forests on Sandy Soils in Northern Germany. Ecosystems 17:497-511.

Lukac M, Godbold DL. 2011. Soil Ecology in Northern Forests: A Belowground View of a Changing World. Cambridge University Press

Macdonald GK, Bennett EM, Taranu ZE. 2012. The influence of time, soil characteristics, and land-use history on soil phosphorus legacies: a global meta-analysis. Global Change Biology 18:1904-17.

McLauchlan K. 2006. The nature and longevity of agricultural impacts on soil carbon and nutrients: A review. Ecosystems 9:1364-82.

Nakagawa S, Schielzeth H. 2013. A general and simple method for obtaining $\mathrm{R}^{2}$ from generalized linear mixed-effects models. Methods in Ecology and Evolution 4:133-42.

Nitsch P, Kaupenjohann M, Wulf M. 2018. Forest continuity, soil depth and tree species are important parameters for SOC stocks in an old forest (Templiner Buchheide, northeast Germany). Geoderma 310:65-76.

Perring MP, De Frenne P, Baeten L, Maes SL, Depauw L, Blondeel H, Carón MM, Verheyen K. 2016. Global environmental change effects on ecosystems: The importance of land-use legacies. Global Change Biology 22:1361-71.

Perring MP, Hedin LO, Levin SA, McGroddy M, de Mazancourt C. 2008. Increased plant growth from nitrogen addition should conserve phosphorus in terrestrial ecosystems. Proceedings of the National Academy of Sciences of the United States of America 105:1971-6.

Peterken G. 1996. Natural Woodland: Ecology and Conservation in Northern Temperate Regions. Cambridge University Press

Pretzsch H, Biber P, Schütze G, Uhl E, Rötzer T. 2014. Forest stand growth dynamics in Central Europe have accelerated since 1870. Nature Communications 5:1-10.

R Core Team. 2017. R: A language and environment for statistical computing. URL: https://www.rproject.org/.

Ringeval B, Augusto L, Monod H, van Apeldoorn D, Bouwman L, Yang X, Achat DL, Chini LP, Van Oost K, Guenet B, Wang R, Decharme B, Nesme T, Pellerin S. 2017. Phosphorus in agricultural soils: drivers of its distribution at the global scale. Global Change Biology 23:3418-32.

Rowe H, Withers PJA, Baas P, Chan NI, Doody D, Holiman J, Jacobs B, Li H, MacDonald GK, McDowell R, Sharpley AN, Shen J, Taheri W, Wallenstein M, Weintraub MN. 2016. Integrating legacy soil phosphorus into sustainable nutrient management strategies for future food, bioenergy and water security. Nutrient Cycling in Agroecosystems 104:393-412. 
piece in the global phosphorus crisis puzzle. Proceedings of the National Academy of Sciences 109:6348-53.

Simkin SM, Allen EB, Bowman WD, Clark CM, Belnap J, Brooks ML, Cade BS, Collins SL, Geiser LH, Gilliam FS, Jovan SE, Pardo LH, Schulz BK, Stevens CJ, Suding KN, Throop HL, Waller DM. 2016. Conditional vulnerability of plant diversity to atmospheric nitrogen deposition across the USA. Proceedings of the National Academy of Sciences of the United States of America 113:4086-91.

Simonis AD, Setatou HB. 1996. Assessment of available phosphorus and potassium in soils by the calcium chloride extraction method. Communications in Soil Science and Plant Analysis 27:68594.

Tao L, Hunter MD. 2012. Does anthropogenic nitrogen deposition induce phosphorus limitation in herbivorous insects? Global Change Biology 18:1843-53.

Tardy V, Spor A, Mathieu O, Lévèque J, Terrat S, Plassart P, Regnier T, Bardgett RD, van der Putten WH, Roggero PP, Seddaiu G, Bagella S, Lemanceau P, Ranjard L, Maron PA. 2015. Shifts in microbial diversity through land use intensity as drivers of carbon mineralization in soil. Soil Biology and Biochemistry 90:204-13.

Vellend M, Baeten L, Becker-scarpitta A, Mccune JL, Messier J, Myers-smith IH, Sax DF. 2017. Plant Biodiversity Change Across Scales During the Anthropocene. Annual Review of Plant Biology:124.

Verheyen K, Baeten L, De Frenne P, Bernhardt-Römermann M, Brunet J, Cornelis J, Decocq G, Dierschke H, Eriksson O, Hédl R, Heinken T, Hermy M, Hommel P, Kirby K, Naaf T, Peterken G, Petř́k P, Pfadenhauer J, Van Calster H, Walther G-R, Wulf M, Verstraeten G. 2012. Driving factors behind the eutrophication signal in understorey plant communities of deciduous temperate forests. Journal of Ecology 100:352-65.

Verheyen K, Bossuyt B, Hermy M. 1999. The land use history ( 1278 - 1990 ) of a mixed hardwood forest in western Belgium and its relationship with chemical soil characteristics. Journal of Biogeography 26:1115-28.

Verheyen K, De Frenne P, Baeten L, Waller DM, Hédl R, Perring MP, Blondeel H, Brunet J, Chudomelová M, Decocq G, De Lombaerde E, Depauw L, Dirnböck T, Durak T, Eriksson O, Gilliam FS, Heinken T, Heinrichs S, Hermy M, Jaroszewicz B, Jenkins MA, Johnson SE, Kirby KJ, Kopecký M, Landuyt D, Lenoir J, Li D, Macek M, Maes SL, Máliš F, Mitchell FJG, Naaf T, Peterken G, Petř́́k P, Reczyńska K, Rogers DA, Schei FHø, Schmidt W, Standovár T, Świerkosz K, Ujházy K, Van Calster H, Vellend M, Vild O, Woods K, Wulf M, Bernhardt-Römermann M. 2017. Combining Biodiversity Resurveys across Regions to Advance Global Change Research. BioScience 67:73-83.

Vesterdal L, Schmidt IK, Callesen I, Nilsson LO, Gundersen P. 2008. Carbon and nitrogen in forest floor and mineral soil under six common European tree species. Forest Ecology and Management 255:35-48.

von Wandruszka R. 2006. Phosphorus retention in calcareous soils and the effect of organic matter on its mobility. Geochemical Transactions 7:1-8.

Wall A, Hytönen J. 2005. Soil fertility of afforested arable land compared to continuously forested sites. Plant and Soil 275:247-60. 
M, Ellis EC, Ellis M, Jeandel C, Leinfelder R, McNeill JR, Richter D d., Steffen W, Syvitski J, Vidas D, Wagreich M, Williams M, Zhisheng A, Grinevald J, Odada E, Oreskes N, Wolfe AP. 2016. The Anthropocene is functionally and stratigraphically distinct from the Holocene. Science 351.

591 Yesilonis I, Szlavecz K, Pouyat R, Whigham D, Xia L. 2016. Historical land use and stand age effects on 592 forest soil properties in the Mid-Atlantic US. Forest Ecology and Management 370:83-92. 